\title{
EVALUASI DALAM PROSES PEMBELAJARAN
}

\author{
Idrus $\mathbf{L}^{1}$
}

\begin{abstract}
Learning evaluation is an activity to collect data and information about students' learning abilities, to assess how far the learning program has been running, and also as a tool to determine whether the educational objectives and learning process in developing science have taken place as they should. In addition, the evaluation also aims to determine the level of student achievement in a learning process, as well as to understand students the extent to which they can provide assistance to the shortcomings of students, with the aim of placing students in a learning situation that is more appropriate to their ability level. The function of learning evaluation is to help the process, progress and development of students' learning outcomes on an ongoing basis, and at the same time be able to know the abilities and weaknesses of students in a particular field of study, while also being able to provide information to parents/guardians of students regarding class ranking or determining graduation of participants students. The evaluation tool requirements are validity, effectiveness, different items and objectivity.
\end{abstract}

Keywords: Evaluation, Instrument, Technique, Education.

\section{PENDAHULUAN}

\section{A. Latar Belakang Masalah}

Pembelajaran merupakan investasi yang paling utama bagi setiap bangsa apalagi bagi bangsa yang sedang berkembang yang giat membangun negaranya. Pembangunan hanya dapat dilakukan oleh manusia yang dipersiapkan melalui pembelajaran, guna mencapai esensi kemanusiaan yaitu sebagai khalifah di atas bumi. ${ }^{2}$ Pengembangan pembelajaran tidak terlepas dari tanggung jawab seorang pendidik, bagaimana pendidik tersebut melakukan transformasi ilmu yang dimiliki dengan bahan ajar yang telah ada, serta dengan memperhatikan metode-metode pengajar yang mudah diterima oleh peserta didik sehingga tujuan tercapai sesuai dengan apa yang diharapkan. Tujuan yang hendak dicapai tersebut, maka dalam proses pembelajaran guru harus melakukan suatu kegiatan yang dinamakan dengan evaluasi. ${ }^{3}$

Evaluasi merupakan bagian dari proses pembelajaran yang secara keseluruhan tidak dapat dipisahkan dari kegiatan mengajar, melaksanakan evaluasi yang dilakukan dalam kegiatan pendidikan mempunyai arti yang sangat utama, karena evaluasi merupakan alat ukur atau proses untuk mengetahui tingkat pencapaian keberhasilan yang telah dicapai peserta didik atas bahan ajar atau materi-materi yang telah disampaikan, sehingga dengan adanya evaluasi maka tujuan dari pembelajaran akan terlihat secara akurat dan meyakinkan.

Evaluasi sebagai bagian dari program pembelajaran perlu dioptimalkan, karena bukan hanya bertumpu pada penilaian hasil belajar, tetapi juga perlu penilaian terhadap in

\footnotetext{
${ }^{1}$ Mahasiswa Program Doktor UIN Alauddin Makassar

${ }^{2}$ Lihat, Nasutioan, Teknologi Pendidikan (Cet.. IV; Jakarta: Bumi Aksara, 2008), h.5.

${ }^{3}$ Lihat, Ibid, h. 6
} 
put, proses, dan out put. Salah satu faktor yang penting untuk efektivitas pembelajaran adalah faktor evaluasi baik terhadap proses belajar maupun terhadap hasil pembelajaran. Evaluasi merupakan kegiatan pengumpulan kenyataan mengenai proses pembelajaran secara sistematis untuk menetapkan apakah terjadi perubahan terhadap peserta didik dan sejauh manakah perubahan tersebut mempengaruhi kehidupan peserta didik. ${ }^{4}$

Evaluasi dapat mendorong peserta didik untuk lebih giat belajar secara terus menerus dan juga mendorong guru untuk lebih meningkatkan kualitas proses pembelajaran serta mendorong pengelola pendidikan untuk lebih meningkatkan fasilitas dan kualitas belajar peserta didik. Sehubungan dengan hal tersebut, optimalisasi sistem evaluasi memiliki dua makna, pertama adalah sistem evaluasi yang memberikan informasi yang optimal. Kedua adalah manfaat yang dicapai dari evaluasi. Manfaat yang utama dari evaluasi adalah meningkatkan kualitas pembelajaran. ${ }^{5}$

Hal tersebut menunjukkan bahwa keberhasilan program pembelajaran selalu dilihat dari aspek hasil belajar yang dicapai. Di sisi lain evaluasi pada program pembelajaran membutuhkan data tentang pelaksanaan pembelajaran dan tingkat ketercapaian tujuan pembelajaran. Kondisi yang demikian tidak hanya terjadi pada jenjang pendidikan tinggi, tetapi juga terjadi dijenjang pendidikan dasar dan menengah. Keberhasilan program pembelajaran selalu dilihat dari aspek hasil belajar, sementara implementasi program pembelajaran di kelas atau kualitas proses pembelajaran itu berlangsung jarang tersentuh kegiatan penilaian.

Dengan demikian evaluasi sangat dibutuhkan dalam berbagai kegiatan kehidupan manusia sehari-hari, karena disadari atau tidak disadari, sebenarnya evaluasi sudah sering dilakukan, baik untuk diri sendiri maupun kegiatan sosial lainnya. Hal ini dapat dilihat mulai dari berpakaian, setelah berpakaian ia berdiri dihadapan cermin apakah penampilannya sudah wajar atau belum, sampai pada hal-hal yang lebih besar dalam kehidupan manusia. Contohnya ketika seorang pejabat negara berakhir masa jabatannya, maka orang lain yang ada disekitarnya akan melakukan penilaian atau evaluasi terhadap kinerjanya selama masa kepemimpinannya. Apakah kepemimpinannya tersebut berhasil atau tidak.

Begitu pula dalam dunia pendidikan tidak dapat dipisahkan dengan kegiatan evaluasi itu sendiri. Dikatakan demikian, karena evaluasi merupakan salah satu komponen dasar dari sistem pendidikan yang harus dilakukan secara sistematis dan terencana sebagai alat untuk mengukur keberhasilan atau target yang akan dicapai dalam proses pembelajaran.

\section{B. Rumusan Masalah}

Berdasarkan dari uraian latar belakang yang telah dikemukakan, maka rumusan masalah pokok yang menjadi pembahasan penulis adalah bagaimana Pengertian, tujuan, kegunaan, fungsi dan manfaat evaluasi dalam proses pembelajaran? Sejalan dengan rumusan masalah pokok tersebut, maka pembahasan ini dibatasi dalam beberapa sub masalah sebagai berikut :

1. Bagaimana pengertian evaluasi belajar peserta didik?

2. Bagaimana tujuan, fungsi, dan manfaat evaluasi belajar peserta didik dalam proses pembelajaran?

3. Bagaimana Syarat penyusunan alat evaluasi dan teknik evaluasi?

\footnotetext{
${ }^{4}$ http/www bloom et al.com. Diakses: 18 Mei 2019.

${ }^{5}$ Gintings Abdorrakhman. Esensi Praktis Belajar dan Pembelajaran (Bandung: Buah Batu, 2008), h.162.
} 


\section{PEMBAHASAN}

\section{A. Pengertian Evaluasi}

Secara etimologi “ evaluasi” berasal dari bahasa Inggris yaitu evaluation dari akar kata value yang berarti nilai atau harga. Nilai dalam bahasa Arab disebut al-qiamah atau al- taqdir' yang bermakna penilaian (evaluasi). Sedangkan secara harpiah, evaluasi pendidikan dalam bahasa Arab sering disebut dengan

al-taqdiraltarbiyah yang diartikan sebagai penilaian dalam bidang pendidikan atau penilaian mengenai hal-hal yang berkaitan dengan kegiatan pendidikan ${ }^{6}$.

Secara terminologi, beberapa ahli memberikan pendapat tentang pengertian evaluasi diantaranya:

Edwind dalam Ramayulis mengatakan bahwa evaluasi mengandung pengertian suatu tindakan atau proses dalam menentukan nilai sesuatu. ${ }^{7}$ Sedangkan M.Chabib Thoha, mendefinisikan evaluasi merupakan kegiatan yang terencana untuk mengetahui keadaan objek dengan menggunakan instrumen dan hasilnya dibandingkan dengan tolok ukur untuk memperoleh kesimpulan ${ }^{8}$

Pengertian evaluasi secara umum dapat diartikan sebagai proses sistematis untuk menentukan nilai sesuatu (ketentuan, kegiatan, keputusan, unjuk-kerja, proses, orang, objek dan yang lainnya) berdasarkan kriteria tertentu melalui penilaian. Untuk menentukan nilai sesuatu dengan cara membandingkan dengan kriteria, evaluator dapat langsung membandingkan dengan kriteria umum, dapat pula melakukan pengukuran terhadap sesuatu yang dievaluasi kemudian membandingkan dengan kriteria tertentu. ${ }^{9}$

Dalam pengertian lain antara evaluasi, pengukuran, dan penilaian merupakan kegiatan yang bersifat hirarki. Artinya ketiga kegiatan tersebut dalam kaitannya dengan proses pembelajaran tidak dapat dipisahkan satu sama lain dan dalam pelaksanaannya harus dilaksanakan secara berurutan. Dalam kaitan ini ada dua istilah yang hampir sama tetapi sesungguhnya berbeda, yaitu penilaian dan pengukuran. Pengertian pengukuran terarah kepada tindakan atau proses untuk menentukan kauntitas sesuatu, karena itu biasanya diperlukan alat bantu. Sedangkan penilaian atau evaluasi terarah pada penentuan kualitas atau nilai sesuatu. ${ }^{10}$.

Evaluasi pembelajaran adalah proses untuk menentukan nilai belajar dan pembelajaran yang dilaksanakan, dengan melalui kegiatan penilaian atau pengukuran belajar dan pembelajaran. Sedangkan pengertian pengukuran dalam kegiatan pembelajaran adalah proses membandingkan tingkat keberhasilan belajar dan pembelajaran dengan ukuran keberhasilan belajar dan pembelajaran yang telah ditentukan secara kuantitatif, sementara pengertian penilaian belajar dan pembelajaran adalah proses pembuatan keputusan nilai keberhasilan belajar dan pembelajaran secara kualitatif ${ }^{11}$

Dengan adanya evaluasi, peserta didik dapat mengetahui sejauh mana keberhasilan yang telah dicapai selama mengikuti pendidikan. Pada kondisi di mana peserta didik mendapatkan nilai yang memuaskan, maka akan memberikan dampak berupa suatu

\footnotetext{
${ }^{6}$ Anas Sudiono, Pengantar Evaluasi Pendidikan, (PT. Grafindo Persada, Jakarta. 2005), h.1.

${ }^{7}$ Ramayulis, Metodologi Pendidikan Agama Islam (Cet. I; Jakarta: Kalam Mulia, 2002), h.331.

${ }^{8}$ M. Chabib Thoha, Teknik Evaluasi Pendidikan (Cet. I; Jakarta: PT. Raja Grafindo, 1990), h.17.

${ }^{9}$ Ahmad Sabri, Strategi Belajar Mengajar,( Cet. I; Jakarta: Ciputat Press, 2005), h. 138.

${ }^{10}$ Lihat Syaiful Bahri Djamarah, Guru Dan Anak Didik Dalam Interaksi Edukatif Suatu Pendekatan Teoritis Psikologis (Cet. II; Jakarta: PT Rineka Cipta, 2005), h. 246.

${ }^{11}$ Ibid, h 37.
} 
stimulus, motivator agar peserta didik dapat lebih meningkatkan prestasi. Pada kondisi di mana hasil yang dicapai tidak memuaskan. maka peserta didik akan berusaha memperbaiki kegiatan belajar, namun demikian sangat diperlukan pemberian stimulus positif dari guru/pengajar agar peserta didik tidak putus asa.

Sedangkan evaluasi dalam pendidikan Islam adalah pengambilan sejumlah yang berkaitan dengan pendidikan Islam guna melihat sejauhmana keberhasilan pendidikan yang selaras dengan nilai-nilai Islam sebagai tujuan dari pendidikan itu sendiri. Lebih jauh Jalaludin mengatakan bahwa evaluasi dalam pendidikan Islam telah menggariskan tolok ukur yang serasi dengan tujuan pendidikannya. Baik tujuan jangka pendek yaitu membimbing manusia agar hidup selamat di dunia, maupun tujuan jangka panjang untuk kesejahteraan di akhirat nanti. Kedua tujuan tersebut menyatu dalam sikap dan tingkah laku yang mencerminkan akhlak yang mulia. Sebagai tolok ukur dan akhlak mulia ini dapat dilihat dari cerminan tingkah laku dalam kehidupan sehari-hari. ${ }^{12}$

Al- Qur'an sebagai dasar segala disiplin ilmu termasuk ilmu pendidikan Islam secara implisit sebenarnya telah memberikan deskripsi tentang evaluasi pendidikan dalam Islam. Hal ini dapat ditemukan dari berbagai sistem evaluasi yang ditetapkan Allah diantaranya:

1. Evaluasi untuk mengoreksi balasan amal perbuatan manusia, sebagaimana yang tersirat dalam QS. Al-Zalzalah: 7-8. ${ }^{13}$

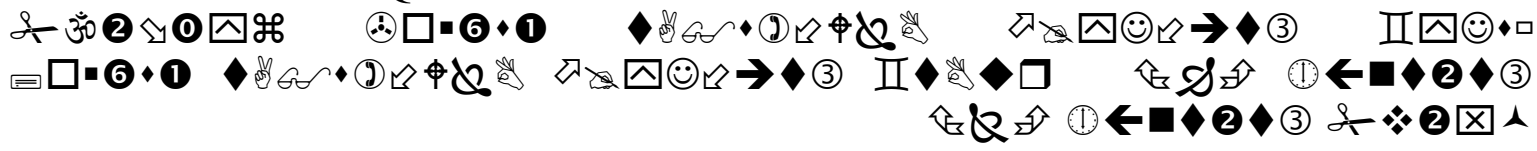

Terjemahnya:

Barangsiapa yang mengerjakan kebaikan seberat dzarrahpun, niscaya Dia akan melihat (balasan)nya dan Barangsiapa yang mengerjakan kejahatan sebesar dzarrahpun, niscaya Dia akan melihat (balasan)nya pula.

2. Nabi Sulaiman As, Pernah mengevaluasi kejujuran seekor burung Hud-hud yang memberitahukan adanya kerajaan yang diperintah oleh seorang wanita cantik, yang dikisahkan dalam Q.S, al Naml: $27^{14}$

* \&

Terjemahnya:

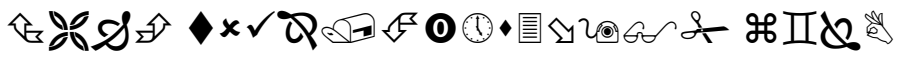

Sulaiman berkata: akan kami cermati (evaluasi) apakah kamu benar ataukah kamu termasuk orang-orang yang berdusta.

3. Sebagai contah ujian (tes) yang berat kepada Nabi Ibrahim as, Allah memerintahkan beliau untuk menyembelih anaknya Ismail yang amat dicintai. Tujuannya untuk mengetahui kadar keimanan dan ketaqwaan serta ketaatannya kepada Allah,seperti disebutkan dalam QS, Al-Shaffat: 103-104. ${ }^{15}$

${ }^{12}$ Lihat Jalaluddin dan Usman Said, Filsafat Pendidikan Islam Konsep dan Perkembangan, (Cet. I; Jakarta, Rajawali Pers, 2006. h.75.

${ }^{13}$ Al Qur'an dan Terjemahnya Departemen Agama RI (Cet. XI: Semarang; Cv.Asy Syifa' 2000), h. 480

${ }^{14}$ Ibid. h. 346.

${ }^{15}$ Ibid, h.254. 


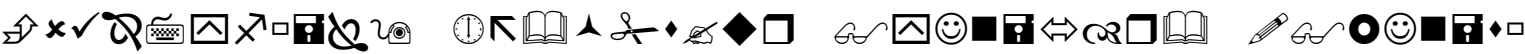 (1) सि है}

Terjemahnya:

Tatkala keduanya telah berserah diri dan ibrahim membaringkan anaknya atas pelipisnya ( nyatalah kesabaran keduanya) Dan kami panggillah dia: Hai Ibrahim. Sesungguhnya kamu telah membenarkan mimpi itu. ${ }^{16}$

Dari beberapa pengertian tersebut di atas baik dari makna bahasa istilah maupun dari ayat al-Qur'an. maka penulis dapat memberikan pengertian bahwa evaluasi merupakan suatu proses tolok ukur untuk mengetahui sejauh mana tingkat keberhasilan yang dicapai dalam dunia pendidikan. Oleh karena itu evaluasi merupakan hal yang signifikan dilakukan dalam dunia pendidikan, karena mempunyai manfaat yang amat berpengaruh, begitu juga dengan bidang-bidang yang lain termasuk dalam kehidupan, dan yang paling utama adalah evaluasi terhadap diri sendiri.

\section{B. Tujuan, Fungsi, dan Manfaat Evaluasi}

\section{Tujuan Evaluasi}

Evaluasi adalah suatu kegiatan yang disengaja dan bertujuan. Kegiatan evaluasi dilakukan dengan sadar oleh guru dengan tujuan untuk memperoleh kepastian mengenai keberhasilan belajar peserta didik dan memberikan masukan kepada guru mengenai apa yang dia lakukan dalam kegiatan pengajaran. Dengan kata lain, evaluasi yang dilakukan oleh guru bertujuan untuk mengetahui bahan-bahan pelajaran yang disampaikan apakah sudah dikuasi oleh peserta didik ataukah belum. Dan selain itu, apakah kegiatan pegajaran yang dilaksanakannya itu sudah sesuai dengan apa yang diharapkan atau belum.

Menurut Sudirman N, dkk, bahwa tujuan penilaian dalam proses pembelajaran adalah:

a. Mengambil keputusan tentang hasil belajar

b. Memahami peserta didik

c. Memperbaiki dan mengembangkan program pembelajaran. ${ }^{17}$

Selanjutnya pengambilan keputusan tentang hasil belajar merupakan suatu keharusan bagi seorang guru agar dapat mengetahui berhasil tidaknya peserta didik dalam proses pembelajaran. Ketidakberhasilan proses pembelajaran itu disebabkan antara lain, sebagai berikut:

a. Kemampuan peserta didik rendah.

b. Kualitas materi pembelajaran tidak sesuai dengan tingkat usia anak.

c. Jumlah bahan pelajaran terlalu banyak sehingga tidak sesuai dengan waktu yang diberikan.

d. Komponen proses pembelajaran yang kurang sesuai dengan tujuan yang telah ditetapkan oleh guru itu sendiri. ${ }^{18}$

Di samping itu, pengambilan keputusan juga sangat diperlukan untuk memahami peserta didik dan mengetahui sampai sejauhmana dapat memberikan bantuan terhadap kekurangan-kekurangan peserta didik. Evaluasi juga bermaksud meperbaiki dan mengembangkan program pembelajaran.

\footnotetext{
${ }^{16}$ Ibid, h. 342.

${ }^{17}$ Lihat, Sudirman dkk, Ilmu Pendidikan (Cet. I; Bandung: Sinar Baru 2005), h. 242.

${ }^{18}$ Lihat, Ibid, h. 243.
} 
Dengan demikian, tujuan evaluasi adalah untuk memperbaiki cara, pembelajaran, mengadakan perbaikan dan pengayaan bagi peserta didik, serta menempatkan peserta didik pada situasi pembelajaran yang lebih tepat sesuai dengan tingkat kemampuan yang dimilikinya. Tujuan lainnya adalah untuk memperbaiki dan mendalami dan memperluas pelajaran, dan yang terakhir adalah untuk memberitahukan atau melaporkan kepada para orang tua/ wali peserta didik mengenai penentuan kenaikan kelas atau penentuan kelulusan peserta didik.

\section{Fungsi Evaluasi}

Evaluasi yang sudah menjadi pokok dalam proses keberlangsungan. Pembelajaran sebaiknya dikerjakan setiap hari dengan skema yang sistematis dan terencana. Guru dapat melakukan evaluasi tersebut dengan menempatkannya satu kesatuan yang saling berkaitan dengan mengimplementasikannya pada satuan materi pembelajaran. Bagian penting lainnya yaitu bahwa guru perlu melibatkan peserta didik dalam evaluasi sehingga secara sadar dapat mengenali perkembangan pencapaian hasil belajar pembelajaran mereka, Sehingga salah satu komponen dalam pelaksanaan pendidikan. Evaluasi mempunyai beberapa fungsi. Berdasarkan UU RI Sisdiknas No.20 Tahun 2003 pasal 58 ayat 1 bahwa evaluasi hasil belajar peserta didik dilakukan untuk membantu proses, kemajun, dan perkembangan hasil belajar peserta didik secara berkesinambungan. ${ }^{19}$

Menurut M. Ngalim Purwanto bahwa kewajiban bagi setiap guru untuk melaksanakan kegiatan evaluasi itu. Mengenai bagaimana dan sampai dimana penguasaan dan kemampuan telah dicapai oleh peserta didik tentang materi dan ketrampilanketrampilan mengenai mata pelajaran yang telah diberikannya. ${ }^{20}$

Dari pendapat tersebut di atas dapat dipahami bahwa evaluasi mutlak dilakukan dan merupakan kewajiban bagi setiap guru dalam setiap saat melaksanakan kegiatan pembelajaran. Disebut demikian, karena menjadi salah satu tugas pokok guru selain mengajar, adalah melaksanakan kegiatan evaluasi. Evaluasi dan kegiatan mengajar merupakan satu rangkaian yang sangat erat di mana antara keduanya tidak dapat dipisahkan. Lebih dari itu juga adalah guru harus mengetahui tugas dan fungsi evaluasi itu sendiri. Dikatakan demikian agar guru mudah menerapkannya untuk menilai kegiatan pembelajaran pada rumusan tujuan yang telah ditetapkannya tercapai. Untuk hal tersebut, berikut penulis juga mengemukakan beberapa pendapat para ahli, yaitu:

Jahja Qohar, mengemukakan bahwa fungsi evaluasi dari sisi peserta didik secara individual, dan dari segi program pengajaran meliputi antara lain:

a. Dilihat dari segi peserta didik secara individu, evaluasi berfungsi: Mengetahui tingkat pencapaian peserta didik dalam suatu proses pembelajaran yaitu:

1) Menetapkan keefektifan pengajaran dan rencana kegiatan.

2) Memberi basis laporan kemajuan peserta didik

3) Menetapkan kelulusan

b. Dilihat dari segi program pengajaran, evaluasi berfungsi:

1) Memberi dasar pertimbangan kenaikan dan promosi peserta didik

2) Memberi dasar penyusunan dan penempatan kelompok peserta didik yang homogen.

3) Diagnosis dan remedial pekerjaan peserta didik.

4) Memberi dasar pembimbingan dan penyuluhan.

\footnotetext{
${ }^{19}$ http: //www.google.Com, dengan judul, Kebijakan pendidikan. tanggal 12 Mei 2019.

${ }^{20}$ Lihat M. Ngalim Purwanto, Ilmu Pendidikan Teoritis dan Praktis (Cet. I; Bandung: PT Remaja Rosdakarya, 2005), h. 26.
} 
5) Dasar pemberian angka dan rapor bagi kemajuan belajar peserta didik

6) Memberi motivasi belajar bagi peserta didik

7) Mengidentifikasi dan mengkaji kelainan peserta didik.

8) Menafsirkan kegiatan sekolah ke dalam masyarakat

9) Untuk mengadministrasi sekolah

10) Untuk mengembangkan kurikulum

11) Mempersiapkan penelitian pendidikan di sekolah. ${ }^{21}$

Dengan demikian dapat di analisis bahwa tampaknya kegiatan tersebut untuk memberikan masukan bagi peserta didik dan pihak sekolah dalam hal mengetahui tentang perkembangan belajar dan perkembangan grafik belajar serta kelulusan peserta didiknya. Semua informasi yang masuk pada pihak lembaga (sekolah) tempat peserta didik belajar tersebut akan menjadi data yang akurat dalam melakukan evaluasi pada pengembangan dan perbaikan sekolah. Lebih-lebih lagi pada bagaimana mengembangkan mutu atau kualitas peserta didik.

Sedangkan Nana Sudjana menjelaskan bahwa, evaluasi berfungsi sebagai berikut:

1) Untuk mengetahui tercapai tidaknya tujuan instruksional khusus. Dengan fungsi ini dapatlah diktahui bahwa tingkat penguasaan bahan pelajaran yang dikuasai oleh peserta didik. Dengan kata lain, dapat diketahui bahwa hasil belajar peserta didik tesebut baik atau tidak baik.

2) Untuk mengetahui keafktifan proses pembelajaran yang dilaksanakan guru. Rendahnya capaian hasil belajar yang diperoleh peserta didik tidak semata-mata disebabkan oleh ketidakmampuan peserta didik itu sendiri. Tetapi boleh jadi karena guru yang kurang bagus dalam mengajar. Dengan penilaian yang dilakukan akan dapat diketahui apakah hasil belajar itu karena kemampuan peserta didik atau juga karena faktor guru, selain itu dengan penilaian tersebut dapat menilai guru itu sendiri dan hasilnya dapat dijadikan sebagai bahan dalam memperbaiki tindakan mengajar berikutnya. ${ }^{22}$

Sementara itu menurut rumusan fungsi yang dipaparkan oleh pihak Departemen Agama RI, bahwa penilaian adalah sebagai berikut:

1) Memberikan umpan balik kepada guru sebagai dasar untuk memperbaiki cara belajar mengajarnya, mengadakan perbaikan bagi peserta didik, serta menempatkan pada situasi belajar mengajar yang lebih tepat sesuai dengan tingkat kemampuan yang dimilki oleh peserta didik.

2) Menentukan nilai hasil belajar peserta didik ang antara lain diperlukan untuk pemberian laporan pada orang tua sebagai penentuan kenaikan kelas dan penentuan kelulusan peserta didik.

3) Menjadi bahan untuk menyusun laporan dalam rangka penyempurnaan program pembelajaran yang sedang berlangsung. ${ }^{23}$

Selain itu, dikemukakan pula pendapat Wayan Nurkencana dkk., sebagai berikut, yaitu:

a. Untuk mengetahui taraf kesiapan peserta didik dalam menempatkan suatu pendidikan tertentu.

\footnotetext{
${ }^{21}$ Lihat Jahja Qohar Al-Haj, Evaluasi Pendidikan Agama (Cet.I; Jakarta: Ciawi Jaya, 2005), h. 3.

${ }^{22}$ Lihat Nana Sudjana, Dasar-Dasar Proses Belajar Mengajar (Cet. I; Bandung: Sinar Baru, 2005), h. 111.

${ }^{23}$ Lihat Departemen Agama RI, Pedoman Sistem Penilaian Madrasah Aliyah (Jakarta: Dirjen Binbaga Islam Proyek Madrasah Aliyah, 1988/1989), h. 2.
} 
b. Untuk mengetahui beberapa jauh hasil yang telah dicapai dalam kegiatan pembelajaran yang dilaksanakan.

c. Untuk mengetahui apakah suatu mata pelajaran yang telah diajarkan dapat dilanjutkan dengan bahan yang baru atau harus diulang kembali.

d. Untuk mendapatkan bahan-bahan informasi dalam memberikan bimbingan tentang jenis pendidikan atau jenis jabatan yang cocok untuk peserta didik tersebut.

e. Untuk mendapatkan bahan-bahan informasi yang menentukan apakah peserta didik dapat dinaikan ke kelas di atasnya atau tidak ataukah ia tetap pada kelas semula.

f. Untuk membandingkan apakah prestasi yang dicapai peserta didik sudah sesuai dengan kapasitasnya atau belum.

g. Untuk menafsirkan apakah peserta didik telah cukup matang untuk dilepaskan kedalam masyarakat atau untuk melanjutkan keperguruan tinggi.

h. Untuk mengetahui taraf efisiensi metode yang dipergunakan dalam lapangan pendidikan. ${ }^{24}$

Dari keseluruhan pendapat para ahli tersebut di atas, dapat dilihat bahwa redaksinyanya berbeda antara satu dengan yang lain. Akan tetapi substansinya bermuara pada satu titik tujuan atau sasaran, yaitu bagaimana dengan fungsi evaluasi tersebut menjadi parameter bagi pihak peserta didik, guru, sekolah, masyarakat, dan orang tua terhadap kegiatan pembelajaran.

Bagi peserta didik dengan evaluasi ia akan mengetahui kemampuan perkembangan grafik belajarnya, apakah ada kemajuan atau tidak, ataukah semakin menurun. Apakah ia naik kelas atau tidak, ataukah ia lulus dalam ujian sekolah atau tidak lulus. Bagi orang tua, mereka akan mudah untuk mengetahui bahwa anaknya memiliki kualitas atau tidak, naik ke kelas berikutnya atau tidak. Ini dapat dilihat dari buku laporan hasil pendidikannya. Begitu juga bagi pihak sekolah. Kepala sekolah serta semua guru-guru akan dapat mengetahui bagaimana perkembangan grafik kelulusan sisiwanya setiap tahun. Demikian juga dengan peserta didik-peserta didiknya yang tidak naik kelas berikutnya.

Masyarakat juga akan mengetahui dengan evaluasi tersebut, apakah sekolahsekolah yang ada di sekelilingnya tersebut memiliki mutu atau kualitas atau tidak. Dan masyarakat dapat membandingkan antara satu sekolah dengan sekolah lain dalam hal menyekolahkan atau melanjutkan pendidikan putra-putrinya. Apalagi masyarakat bila menjadikan out-put dari lembaga pedidikan itu untuk menjadi tenaga kerja yang siap pakai, lalu bagaimana dengan produktifitasnya sehubungan dengan latar belakang keilmuan yang dimilki itu. Jadi masyarakat sebagai pengguna tenaga lulusan dari sekolah itu akan melihat dengan sendirinya dari hasil evaluasi itu sendiri.

Selain fungsi-fungsi tersebut di atas, berikut dikemukakan beberapa fungsi evaluasi, antara lain:

\section{Penilaian berfungsi selektif}

Dengan cara mengadakan penilaian guru mempunyai cara untuk mengadakan seleksi atau penilaian terhadap peserta didiknya. Penilaian itu sendiri mempunyai berbagai tujuan, antara lain :

a. Untuk memilih peserta didik yang dapat diterima di sekolah tertentu.

b. Untuk memilih peserta didik yang dapat naik kelas ke tingkat berikutnya.

c. Untuk memilih peserta didik yang seharusnya mendapat beasiswa.

${ }^{24}$ Lihat Wayan Nurkancana dan Sumartana, Evaluasi Pendidikan (Surabaya: Usaha Nasional, 2005), h. 3 . 
d. Untuk memilih peserta didik yang sudah berhak meninggalkan sekolah dan sebagainya. ${ }^{25}$

2. Penilaian berfungsi diagnostik

Apabila alat yang digunakan dalam penilaian cukup memenuhi persyaratan, maka dengan melihat hasilnya, guru akan mengetahui kelemahan peserta didik. Di samping itu, diketahui pula sebab-musabab kelemahan itu. Jadi dengan mengadakan penilaian, sebenarnya guru mengadakan diagnosis kepada peserta didik tentang kebaikan dan kelemahannya. Dengan diketahuinya sebab-sebab kelemahan ini, akan lebih mudah dicari cara untuk mengatasi.

\section{Penilaian berfungsi sebagai penempatan}

Sistem baru yang kini banyak dipopulerkan di negara barat, adalah sistem belajar sendiri. Belajar sendiri dapat dilakukan dengan cara mempelajari sebuah paket belajar, baik itu berbentuk modul maupun paket belajar yang lain. Sebagai alasan dari timbulnya sistem ini adalah adanya pengakuan yang besar terhadap kemampuan individual. Setiap peserta didik sejak lahirnya telah membawa bakat sendiri-sendiri sehingga pelajaran akan lebih efektif apabila disesuaikan dengan pembawaan yang ada. Akan tetapi disebabkan karena keterbatasan sarana dan tenaga, pendidikan yang bersifat individual kadang-kadang sukar sekali dilaksanakan. Pendekatan yang lebih bersifat melayani perbedaan kemampuan, adalah pengajaran secara kelompok. Untuk dapat menentukan dengan pasti di kelompok mana seorang peserta didik harus ditempatkan, digunakan suatu penilaian. Sekelompok peserta didik yang mempunyai hasil penilaian yang sama, akan berada dalam kelompok yang sama dalam belajar.

4. Penilaian berfungsi sebagai pengukur keberhasilan

Fungsi keempat dari penilaian ini dimaksudkan untuk mengetahui sejauh mana suatu program berhasil diterapkan. keberhasilan program ditentukan oleh beberapa faktor yaitu faktor guru, metode mengajar, kurikulum, sarana, dan sistem administrasi. ${ }^{26}$

\section{Manfaat Evaluasi}

Secara umum manfaat yang dapat diambil dari kegiatan evaluasi dalam pembelajaran, yaitu :

a. Memahami sesuatu : entry behavior, motivasi, dll, sarana dan prasarana, dan kondisi peserta didik dan dosen

b. Membuat keputusan : kelanjutan program, penanganan "masalah", dll

c. Meningkatkan kualitas PBM : komponen-komponen PBM

Sementara secara lebih khusus evaluasi akan memberi manfaat bagi pihak-pihak yang terkait dengan pembelajaran, seperti peserta didik, guru, dan kepala sekolah. Bagi Peserta didik, Mengetahui tingkat pencapaian tujuan pembelajaran : Memuaskan atau tidak memuaskan, Bagi Guru pertama, mendeteksi peserta didik yang telah dan belum menguasai tujuan : melanjutkan, remedial atau pengayaan, kedua, ketepatan materi yang diberikan : jenis, lingkup, tingkat kesulitan, dll. Ketiga, ketepatan metode yang digunakan dan Bagi Sekolah pertama, hasil belajar cermin kualitas sekolah, kedua, membuat program sekolah, ketiga, pemenuhan standar ${ }^{27}$

Dengan demikian dapatlah di fahami bahwa evaluasi sangat perlu/bermanfaat dan merupakan syarat mutlak untuk perbaikan, agar mempunyai makna yang signifikan bagi semua pihak. Jika di temukan hubungan antara hasil belajar dengan efektivitas metode

${ }^{25}$ M. Ngalim Purwanto, Sosial Pendidikan Teoritis dan Praktis (Cet. I; Bandung: Remaja Rosda Karya, 2001), h. 55

${ }^{26}$ Hamdani Ihsan dkk, Filsafat Pendidikan Islam, (Cet. III. Pustaka Setia Bandung. 2007) h. 219

${ }^{27}$ Slameto, Belajar dan Faktor yang Mempengaruhinnya (Cet. IV; Jakarta: Rineka Cipta, 2003), h. 1 
mengajar terbukalah kemungkinan untuk mengadakan perbaikan. Sebelum kita mengevaluasi kemampuan metode baru pada sejumlah peserta didik, perlu kita pikirkan bahwa proses pembelajaran itu dinamis, senantiasa terjadi perubahan pada guru maupun murid dalam interaksi itu. Disamping hasil belajar seperti diharapkan oleh guru mungkin timbul pula hasil sampingan yang positif maupun negatif. misalnya, peserta didik menguasai bahan yang disajikan akan tetapi ia disamping itu merasa senang atau benci terhadap tindakan pribadi gurunya.

\section{Syarat dan Petunjuk dalam Menyusun Tes dan Teknik Evaluasi}

\section{Syarat dan Petunjuk dalam Menyusun Tes}

Adapun syarat-syarat dalam menyusun tes atau alat evaluasi

\section{a. Validitas}

Validitas sering diartikan dengan kesahihan. Suatu tes dikatakan valid apabila mengukur apa yang seharunya diukur. Meter valid apabilah dipergunakan untuk mengukur jarak, sedangkan timbangan valid apabila dipergunakan untuk mengukur berat. ${ }^{28}$

Menurut Suharsimi Arikunto terdapat 4 (empat) macam validitas yang berasal dari dasar pembagian jenisnya yaitu;

Pertama, validitas isi, suatu tes dikatakan memiliki validitas isi (content validity) apabila mengukur kesejajaran antara tujuan khusus pembelajaran atau indikator pembelajaran dengan materi pokok atau isi pelajaran yang diberikan. Misalnya bila ingin mengukur kemamuan pemahaman mata pelajaran fiqih umpamanya, maka item-item tes yang dibuat diambilkan dari materi pelajaran fiqih pada kurikulum kelas yang kita ajar. Karena aitem-aitem tes yang dibuat mengacu pada kurikulum validitas isi sering disebut juga dengan validitas kurikuler. ${ }^{29}$

Kedua, validitas konstruksi, yaitu suatu tes dikatakan memiliki validitas konstruk apabila aitem-aitem tes yang membangung tes tersebut mengukur semua aspek berfikir dari tujuan pembelajaran khusus atau indikator pembelajaran. Misalnya indikator pembelajaran dalam mata pelajaran fiqhi maka perintah soal harus menunjukkan pada materi pelajaran fiqhi. ${ }^{30}$

Ketiga, validitas ada sekarang atau validitas pengalaman atau empiris. Suatu tes memiliki validitas empiris apabila hasil tes dipasangkan dengan pengalaman akan menghasilkan hasil yang sama. Misalkan untuk mengetahui valid atau tidaknya tes yang dibuat sekarang dibandingkan dengan hasil ujian semester atau hasil ujian tahun yang lalu dengan cara membandingkan aitem-aitem tes yang dibuat sekarang dengan aitem-aitem tes yang telah dibuat pada masa lalu.

Keempat, validitas Prediksi, Suatu tes dikatakan memiliki validitas prediksi apabila tes tersebut memiliki kemampuan untuk memprediksikan prestasi yang akan dicapai seseorang di masa yang akan datang. Misalkan hasil seleksi masuk keperguruan tinggi. ${ }^{31}$ Dari hasil tes tersebut dapat diperkirakan tingkat kesuksesan seseorang diperguruang tinggi sebagai mahasiswa pada masa yang akan datang.

${ }^{28}$ Lihat K. Condie R. Livingston, Evaluation of the Assessment is for Learning Programe (Cet. I; Final Report. Glosgow University of Starthcyde, 2006), h. 67

${ }^{29}$ Lihat Hilgard dan Brower, Modern Philosophies of Education. (Cet. I; New Delhi: Tata GrawHill Publishing Company LTD, 1981), h. 75.

${ }^{30}$ Lihat A.M. Sardiman, Interaksi dan Motifasi Belajar Mengajar (Cet. III; Jakarta: PT Raja Grafindo Persada, 2001), h 34.

${ }^{31}$ Lihat Suharsimi Arikunto, Dasar-Dasar Evaluasi Pendidikan (Cet. IV; Jakarta Bumi Aksarah, 1999), h. 64. 


\section{b. Reliabilitas}

Reliabilitas sering disebut juga tarap kepercayaan dan sering disebut juga dengan keterandalan. Suatu tes dikatakan memiliki reliabilitas apabila tes tersebut dipergunakan untuk mengukur secara berulang-ulang memberikan hasil yang tetap atau sama. ${ }^{32}$

Penilaian yang reliable (terpercaya) memungkinkan perbandingan yang reliable dan menjamin konsistensi. Misalnya, guru menilai kompetensi siswa dalam melakukan eksperimen kimia dalam laboratorium. Tiga puluh siswa melakukan eksperimen dan masing-masing menulis laporannya. Penilaian ini reliable jika guru dapat membandingkan taraf penguasaan 30 siswa itu dengan kompetensi eksperimen yang dituntut dalam kurikulum. Penilaian ini reliable jika 30 siswa yang sama mengulangi eksperimen yang sama dalam kondisi yang sama dan hasilnya ternyata sama.

\section{c. Daya Beda Butir}

Beda butir terdiri dalam dua kategori, yaitu beda atau ananisis butir soal secara kuantitatif dan secara kualitatif. Analisis butir soal secara kuantitatif menekankan pada analisis karakteristik internal tes melalui data yang diperoleh secara empirik. Karakteristik internal yang dimaksud meliputi para meter butir soal tingkat kesukaran , daya pembeda dan reliabilitas. ${ }^{33}$

Daya beda butir dimaksudkan mengkaji soal-soal tes dari segi kesanggupan tes tersebut dalam membedakan siswa yang memiliki kemampuan rendah dengan siswa yang memiliki kemampuan tinggi. Surapranata menyatakan bahwa salah satu tujuan dilakukannya analisis adalah untuk meningkatkan kualitas soal, yaitu apakah suatu soal (1) dapat diterima karena telah didukung oleh data statistik yang memadai (2) diperbaiki, karena terbukti terdapat beberapa kelemahan, atau bahkan (3) tidak digunakan sama sekali karena terbukti secara empiris tidak berfungsi sama sekali. ${ }^{34}$

\section{d. Efektifitas}

Yang dimaksud dengan Efektifitas suatu tes adalah bahwa pelaksanaan tes/penilaian tersebut tidak membutuhkan ongkos/biaya yang mahal, tenaga yang banyak dan waktu yang lama. ${ }^{35}$ Dalam melaksanakan tes ada target yang ingin dicapai serta melihat berbagai kondisi yang dihadapi, seperti kondidi keuangan suatu institusi, lokasi waktu yang diatur oleh pihak pengelola, dan lain-lain, seorang guru yang baik dan arif selalu mempertimbangkan semua hal-hal yang inging direncanakan.

\section{e. Obyektifitas}

Penilaian harus dilaksanakan secara obyektif. Untuk itu, penilaian harus adil, terencana, berkesinambungan, menggunakan bahasa yang dapat dipahami siswa, dan menerapkan kriteria yang jelas dalam pembuatan keputusan atau pemberian angka (skor). Seoramg guru dalam memberikan tes pada siswanya betul-betul ada target yang ingin dicapai dalam proses pembelajaran. Begitu pula dalam membuat dan memberi penilaian dalam tes ia bersikap netral. ${ }^{36}$

Dalam pelaksanaan kurikulum berbasis kompetensi, penilaian harus terfokus pada pencapaian kompetensi (rangkaian kemampuan), bukan pada penguasaan materi (pengetahuan). Penilaian harus menyeluruh dengan menggunakan beragam cara dan alat

\footnotetext{
${ }^{32}$ Lihat Ibid, h. 205.

${ }^{33}$ Mansyur, Asesmen Pembelajaran di Sekolah (Cet. I; Yogyakarta; Multi Presindo, 2009), h. 145

${ }^{34}$ Lihat Ibid, h. 146

${ }^{35}$ Lihat Ibid, h. 71

${ }^{36}$ Lihat Ibid, h. 72
} 
untuk menilai beragam kompetensi atau kemampuan siswa, sehingga tergambar profil kemampuan siswa. ${ }^{37}$

Penilaian dilakukan bukan untuk mendiskriminasi siswa (lulus atau tidak lulus) atau menghukum siswa tetapi untuk mendiferensiasi siswa (sejauh mana seorang siswa membuat kemajuan atau posisi masing-masing siswa dalam rentang cakupan pencapaian suatu kompetensi). Berbagai aktivitas penilaian harus memberikan gambaran kemampuan siswa, bukan gambaran ketidakmampuannya.

\section{Teknik Evaluasi}

Ada dua hal teknik evaluasi untuk menilai kualitas siswa yaitu

a. Tes

Tes merupakan sejumlah pertanyaan yang memiliki jawaban yang benar atau salah. Tes diartikan juga sebagai sejumlah pertanyaan yang membutuhkan jawaban, atau sejumlah pernyataan yang harus diberikan tanggapan dengan tujuan mengukur tingkat kemampuan seseorang atau mengungkap aspek tetentu dari orang yang dikenai tes. Hasil tes merupakan informasi tentang karakteristik seseorang atau sekelompok orang. Tese merupakan salah satu cara untuk menaksir besarnya tingkat kemampuan manusia secara tidak langsung, yaitu melalui respons seseorang terhadap sjumlah stimulusatau pertanyaan. Oleh karena itu, agar diperoleh informasi yang akurat dibutuhkan tes yang handal. ${ }^{38}$

Hasil tes bisa digunakan untuk memantau perkembangan mutu pendidikan. Hasil tes untuk tujuan ini harus baik, yaitu memilki kesalahan pengukuran yang sekecil mungkin. Kesalahan Kesalahan pengukuran ini dapat dikategorikan menjadi dua, yaitu kesalahan acak dan sistemik. Kesalahan acak disebabkan karena kesalahan dalam menentukan sampel isi tes, variasi emosi seseorang, termasuk variasi emosi pemeriksa lembar jawaban jika lembar jawabanpeserta tes diperiksa secara manual. Sedangkan keslahan sistemik adalah kesalahan yang disebabkan karena soal tes terlalu mudah atau terlalu sukar. Ada pendidik yang cenderung membuat tes yang terlalu sulit, tetapi ada juga yang cenderung selalu membuat tes yang mudah. Selain itu ada pula pendidik yang pemurah,dan ada yang mahal dalam memberi skor. Hal-hal ini merupakan sumber kesalahan yang sistemik. ${ }^{39}$

Beberapa istilah yang sering digunakan dalam kaitan dengan tes, yaitu testing, testee, dan tester. Testing adalah waktu dimana tes dilaksanakan, atau waktu pelaksanaan tes. Testee adalah orang yang dikenai tes, atau orang yang mengerjakan tes. Sedangkan tester adalah orang melakukan tes, atau pelaksana tes.

\section{b. Non tes}

Dalam proses belajar mengajar (pembelajaran), penilaian merupakan bagian yang tidak terpisahkan, satu kesatuan yang utuh dengan pembelajaran. Dalam konsep kurikulum berbasis kompentensi seperti K13, menuntut terpenuhinya tiga ranah sebagai indikator keberhasilan. Tiga ranah ini adalah kemampuan berpikir, keterampilan melakukan pekerjaan, dan perilaku. Setiap siswa memiliki potensi pada dua ranah, yaitu kemampuan berpikir dan ketarampilan, namun tingkatannya dari satu siswa ke siswa yang lain bisa berbeda. ${ }^{40}$ Ada siswa yang memiliki kemampuan berpikir tinggi, namun keterampilan rendah. Demikian juga sebaliknya, ada peserta didik yang memiliki kemampuan berpikir rendah, namun memiliki keterampilan yang tinggi. Ada pula peserta didik yang memiliki kemampuan berpikirnya biasa, demikian pula keterampilannya juga biasa, tidak ada yang

${ }^{37}$ Lihat Suatu Inovasi dalam Pendidikan Matematika di Indonesia di akses tanggal 9 Mei 2019 dari http/ www. cascadeimie. com.

${ }^{38}$ Lihat Ibid, h. 142.

${ }^{39}$ Mansyur, op. cit, h. 157.

${ }^{40}$ Lihat Ibid, h. 158. 
menonjol. Namun jarang sekali ada peserta didik yang memiliki kemampuan berpikirnya rendah dan keterampilannya rendah. Karena apabila demikian, sulit bagi peserta didik untuk bisa hidup dimasyarakat, karena tidak memiliki potensi untuk hidup di masyarakat.

Hampir semua pelajaran memerlukan kemampuan berpikir. Kemampuan berpikir termasuk pada ranah kognitif, meliputi kemampuan menghapal, kemampuan memahami, kemampuan menerapkan, kemampuan menganalisis, kemampuan menevaluasi, dan kemampuan mencipta atau dalam istilah taksonomi hasil revisi taksonomi Bloom yaitu mampu untuk menguasai dimensi proses kognitif. Kemampuan yang penting pada ranah kognitif adalah kemampuan menerapkan konsep-konsep untuk memecahkan masalah yang ada dilapangan. Kemampuan ini sering disebut dengan kemampuan menstransfer pengetahuan ke berbagai situasi sesuai dengan konteksnya. Hal ini berkaitan dengan pembelajaran kontekstual. Hampir semua mata pelajaran berkaitan dengan kemampuan kognitif, karena didalamnya diperlukan kemampuan berpikir untuk memahaminya. ${ }^{41}$

Kemampuan yang kedua adalah keterampilan psikomotor, yaitu kemampuan yang berkaitan dengan gerak, yaitu yang menggunakan otot seperti lari, melompat, melukis, berbicara, menbongkar dan memasang peralatan, dan sebagainya. Peringkat kemampuan psikomotorik ada lima, yaitu gerakan reflek, garakan dasar, kemampuan perseptul, kemampuan fisik, gerakan terampil, dan komunikasi nondiskursip. Gerakan reflek adalah respon motor atau gerak tenpa sadar yang muncul ketika bayi lahir. Gerakan dasar adalah gerakan yang mengarah pada keterampilan komplek yang khusus. Siswa yang telah mencapai kompetensi dasar pada ranah ini mampu melakukan tugas dalam bentuk keterampilan sesuai dengan standar atau kriteria. ${ }^{42}$

Kemampuan perceptual adalah kombinasi kemampuan kognitif dan kemampuan motor atau gerak. Kemampuan fisik adalah kemampuan untuk mengembangkan gerakan yang paling terampil. Gerakan termpil adalah gerakan yang mampu dilakuakan siswa sehingga menghasilkajn produk yang optimal, seperti keterampilan melakukan gerak tari, keterampilan mengendarai sepeda atau sepeda motor. Untuk mencapai gerakan terampil, pesertab didik harus belajar secarasistemati melalui langkah-langkah tertentu. Gerakan yang telah dipelajari peserta didik akan tersimpan lama, sehingga apabila siswa salah dalam mempelajari gerakan psikomotot maka sulit untuk memperbaikinya. Oleh karena itu guru harus merancang dengan baik pembelajaran psikomotor sehingga mencapai standar.

Ada dua acuan yang digunakan dalam melakukan teknik penilaian dalam evaluasi, yaitu acuan norma dan acuan kriteria. Kedua acuan ini menggunakan asumsi yang berbeda tentang kemampuan seseorang. Teknik analisis butir pada kedua acuan ini ada yang sama namun ada yang berbeda. Asumsi yang berbeda akan menghasilkan informasi yang berbeda. Penafsiran hasil antara kedua acuan ini berbeda sehingga menghasilkan informasi yang berbeda maknanya. Pemilihan acuan yang tepat ditentukan oleh karakteristik bidang studi yang diukur dan tujuan yang dicapai. ${ }^{43}$

Dilihat dari perencanaan tes dan penafsiran hasil tes, pengukuran dalam bidang pendidikan bisa didasarkan acuan norma atau acuan kriteria. Acuan norma dan kriteria dalam memilih bahan tes pada prinsispnya tidak berbeda, namun dalam penafsiran hasil tes yang berbeda. Perbedaan ini disebabkan asumsi yang berbeda.

${ }^{41}$ J. Umar, Pengembangan Sistem Penilaian untuk Meningkatkan Mutu Pendidikan Nasional di Era Global (Cet. I; Yogyakarta: HEPI, 2007), h. 140.

${ }^{42}$ Zamproni, Pengembangan Sistem Penilaian Pendidikan Menengah yang Menerapkan KBK dalam Kerangka Otonomi Daerah, (Cet. II; Yogyakarta: HEPI, 2004), h. 356.

${ }^{43}$ Ibid, h. 16 
Glaser menyatakan bahwa terdapat dua strategi pengukuran yang mengarah pada dua perbedaan tujuan substansial, yaitu pengukuran acuan norma (NRM) yang berusaha menetapkan status relatif, dan pengukuran acuan kriteria (CRM) yang berusaha menetapkan status absolut. Untuk menggambarkan tes prestasi siswa dengan menekankan pada tingkat ketajaman suatu pemahaman relatif siswa. Sedangkan untuk mengukur tes yang mengidentifikasi ketuntasan / ketidaktuntasan absolut siswa atas perilaku spesifik, menggunakan konsep pengukuran acuan kriteria (Criterion Reference Measurement. ${ }^{44}$ )

Menurut penulis bahwa ada dua acuan yang digunakan dalam teknik menyiapkan tes dan menafsirkan hasil tes, yaitu acuan norma dan acuan kriteria. Kedua acuan ini menggunakan asumsi yang berbeda tentang kemampuan seseorang. Penafsiran hasil tes antara kedua acuan ini berbeda sehingga menghasilkan informasi yang berbeda maknanya. Pemilihan acuan yang tepat ditentukan oleh karakteristik bidang studi yang akan diukur dan tujuan yang akan dicapai.

\section{PENUTUP}

\section{A. Kesimpulan}

Berdasarkan pada uraian pembahasan tersebut di atas maka penulis dapat menarik kesimpulan sebagai berikut:

1. Evaluasi merupakan suatu kegiatan mengumpulkan data dan informasi mengenai kemampuan belajar peserta didik, untuk menilai sudah sejauhmana program (pengembangan sistem instruksional) telah berjalan, dan juga sebagai suatu alat untuk menentukan apakah tujuan pendidikan dan proses pembelajaran dalam mengembangkan ilmu pengetahuan telah berlangsung sebagaimana mestinya.

2. Evaluasi bertujuan untuk mengetahui tingkat pencapaian peserta didik dalam suatu proses pembelajaran, sekaligus untuk memahami peserta didik tentang sejauhmana dapat memberikan bantuan terhadap kekurangan-kekurangan peserta didik, dengan tujuan menempatkan peserta didik pada situasi pembelajaran yang lebih tepat sesuai dengan tingkat kemampuan yang dimilikinya. Sedangkan fungsi evaluasi untuk membantu proses, kemajuan dan perkembangan hasil belajar peserta didik secara berkesinambungan, dan sekaligus dapat mengetahui kemampuan dan kelemahan peserta didik pada bidang studi tertentu, sekaligus dapat memberikan informasi kepada orang tua /wali peserta didik mengenai penentuan kenaikkan kelas atau penentuan kelulusan peserta didik.

3 Syarat alat evaluasi yaitu memiliki Validitas, Efektifitas, Beda Butir dan Obyektifitas. Suatu tes dikatakan valid, efektif apabila pelaksanaan tes tersebut tidak membutuhkan ongkos/biaya yang mahal, tenaga yang banyak dan waktu yang lama. Dan juga dikatakan praktis apabila penilaian itu mudah pengadimistrasiannya dan mudah dilaksanakan, mudah memeriksanya, dan dilengkapi dengan petunjuk-petunjuk yang jelas sehingga dapat diberikan/ diawali oleh orang lain dan teknik evaluasi melalui dua cara yaitu melaui tes dan non tes dan acuan norma dan acuan kreteria.

\footnotetext{
${ }^{44}$ Lihat, Mansyur, op. cit, h. 46
} 


\section{DAFTAR RUJUKAN}

Abdorrakhman, Gintings. Esensi Praktis Belajar dan Pembelajaran: Buah Batu Bandung th 2008.

Al-Haj, Jahja Qohar, Evaluasi Pendidikan Agama Cet.I; Jakarta: Ciawi Jaya, 1985.

Arikunto, Suharsimi. Dasar-Dasar Evaluasi Pendidikan. Cet. IV; Jakarta Bumi Aksarah, 1999.

Departemen Agama RI, Pedoman Sistem Penilaian Madrasah Aliyah. Jakarta Dirjen Binbaga Islam Proyek Madrasah Aliyah, 1988/1989.

Departemen Pendidikan dan Kebudayaan, Kamus Besar Bahasa Indonesia,Cet. V: Jakarta 1976.

Dimyati dan Mujiono. Belajar dan Pembelajaran. Cet. III; Jakarta Cipta, 2006.

Djamarah, Syaiful Bahri. Guru Dan Anak Didik Dalam Interaksi Edukatif Suatu Pendekatan Teoritis Psikologis Cet. II; Jakarta: PT Rineka Cipta, 2005.

E.N. Gronlund, Improving Marking and Reporting in Classroom Instruction, Macmillan Publishing Co, Inc.New Yok, Collier Macmillan Publishers, London, 1974.

Hergenhanhn, B. R. dan Matthew H. Olson, Theories of Learning (Teori Belajar) Edisi Ketujuh. Cet. 1. Jakarta: Kencana, 2008.

Hilgard dan Brower, Modern Philosophies of Education. Cet. I; New Delhi: Tata GrawHill Publishing Company LTD, 1981.

http/www bloom et. All. com. Tanggal 12 Mei 2019.

J.B. Sykes (ed), The Concise Oxford Dictionary of Corred English (Oxford: Calredom Press; 1976.

Livingston, K. Condie R. Evaluation of the Assessment is for Learning Programe. Cet. I; Final Report. Glosgow University of Starthcyde, 2006.

Mansyur, Asesmen Pembelajaran di Sekolah. Cet. I; Yogyakarta; Multi Presindo, 2009

Muijs, Daniel. Dan David Reynolds, Effective Teaching Second Edition diterjemahkan oleh Helly Prajitno Soetjipto dan Sri Mulyantini S0etjipto dengan judul Teori dan Aplikasi Edisi Kedua Cet. I, Yogyakarta: Pustaka Pelajar, 2008.

Nasution., Teknologi Pendidikan, Jakarta: Bumi Aksara, 2008.

Nurkencama, Wayan. dan Sumartana, Evaluasi Pendidikan Surabaya: Usaha Nasional, 1983.

Purwanto, M. Ngalim. Ilmu Pendidikan Teoritis dan Praktis Bandung: PT Remaja Rosdakarya, 2006.

Rosda Karya, 2005.

Ramayulis, Metodologi Pendidikan Agama IslamKalam Mulia: Jakarta 2002.

Sabri, Ahmad, Strategi Belajar Mengajar, Cet. I. Ciputat Press. 2005. 
Salim, Peter. The Contenporary English Indonesia Dictionary. Ed II. Jakarta: Modern English Press, 1986.

Sardiman, A.M. Interaksi dan Motifasi Belajar Mengajar. Cet. III; Jakarta: PT Raja Grafindo Persada, 2001.

Slameto, Belajar dan Faktor yang Mempengaruhinnya. Cet. IV; Jakarta: Rineka Cipta, 2003.

Sudiono, Anas. Pengantar Evaluasi Pendidikan, PT. Grafindo Persada, Jakarta. 2005.

Sudirman dkk, Ilmu Pendidikan, Cet. I; Bandung: Sinar Baru 1991.

Sudjana, Nana. Dasar-Dasar Proses Belajar Mengajar Bandung: Sinar Baru, 2005.

Thoha, M. Chabib. Teknik Evaluasi Pendidikan PT. raja Grafindo : Jakarta, 2005.

Umar, J. Pengembangan Sistem Penilaian untuk Meningkatkan Mutu Pendidikan Nasional di Era Global. Cet. I; Yogyakarta: HEPI, 2007.

Zamproni, Pengembangan Sistem Penilaian Pendidikan Menengah yang Menerapkan KBK dalam Kerangka Otonomi Daerah, Cet. II; Yogyakarta: HEPI, 2004. 